\title{
PENGARUH MODEL PEMBELAJARAN QUANTUM TEACHING TERHADAP HASIL BELAJAR FREE THROW BOLABASKET
}

\author{
Nurdian Ahmad ${ }^{1)}$, Yudi Dwi Saputra ${ }^{2)}$ \\ ${ }^{1}$ Program Studi Pendidikan Jasmani dan Kesehatan STKIP PGRI Jombang \\ Email: nurdian.ahmad030485@gmail.com \\ ${ }^{2}$ Program Studi Pendidikan Jasmani dan Kesehatan STKIP PGRI Jombang \\ Email: yudids31@gmal.com
}

\author{
Artikel Info \\ Korespondenpenulis: \\ Nurdian Ahmad \\ Nurdian.ahmad030485@gmail.com \\ $\square$ Diterima 8 April 2021 \\ $\square$ Direview 11 Juli 2021 \\ $\square$ Disetujui 16 Juli 2021 \\ $\square$ Dipublikasi 17 Juli 2021 \\ Kata Kunci: \\ Quantum Teaching, Free Throw, Bolabasket
}

\begin{abstract}
Abstrak
Tujuan penelitian ini adalah untuk mengetahui ada atau tidaknya peningkatan pemebelajaran melalui Quantum teaching terhadap hasil belajar free throw dalam permainan bolabasket. Penelitian yang digunakan dalam penelitian ini adalah ekperimen. Sampelnya adalah kelas XI TKJ SMK Dwija Bhati Jombang. Berdasarkan dari data yang diperoleh hasil nilai pre-test rata-rata sebesar 51,83, sedangkan nilai post-test mengalami peningkatan dengan nilai rata-rata 68,81 . Untuk uji-t diperoleh nilai thitung lebih besar dari table atau thitung $=10,44>\mathrm{t}_{\mathrm{table}}=1,73$. Dengan demikian terdapat pengaruh penerapan pembelajaran Quantum Teaching terhadap hasil belajar free throw dalam permainan bolabasket dengan peningkatan sebesar 16,98\%.
\end{abstract}

\section{Abstract}

The purpose of the research is to determine wheter there is an increase in learning throught Quantum teaching on learning outcomes in free throw of basketball. The research used in this studi is experimental research. Sample is XI TKJ in SMK Dwija Bhakti Jombang. Based on the data that has been obtained the result of average of pre-test of free throw in the game of basketball is 51,83, while average of post-test is 68,81 . For the t-test values obtain taritmetic is bigger than $t_{\text {table }}$ or taritmetic $=10,44>t_{\text {table }}=1,73$. So there is effect of applicated Quantum teaching learning method to influence learning outcomes of free throw in the game of baseketball with an increase as many as $16,98 \%$.
Keywords:

Quantum Teaching, Free Throw, Basketball 


\section{PENDAHULUAN}

Pendidikan jasmani merupakan media untuk mendorong perkembangan motorik, kemampuan fisik, serta pembiasan pola hidup sehat yang bermuara untuk merangsang pertumbuhan dan perkembangan yang seimbang. Menurut Anwar (2005: 48) menyatakan bahwa pendidikan jasmani merupakan proses pendidikan yang memanfaatkan aktivitas jasmani dan direncanakan secara sistematik bertujuan untuk meningkatkan individu secara organik, neuromuskuler, perseptual, kognitif, sosial dan emosional. Lebih jauh lagi dijelaskan bahwa pendidikan merupakan bagian integral dari sistem pendidikan secara keseluruhan, yang memfokuskan pengembangan aspek kebugaran jasmani, keterampilan gerak, keterampilan berfikir kritis, stabilitas emosional, keterampilan sosial, penalaran, dan tindakan moral melalui aktivitas jasmani. Adapun tujuan pendidikan jasmani olahraga dan kesehatan yang dipaparkan oleh ( Sudianto, 2005: 30 - 31) adalah untuk membantu peserta didik dalam meningkatkan derajat kesegaran jasmani, keterampilan gerak, dan kesehatan melalui pengenalan dan penanaman sikap positif, pematangan sikap mental dalam berbagai kegiatan jasmani. Oleh karena itu sistem pengajaran dalam pendidikan jasmani harus disesuaikan dengan perkembangan anak, isi dan urutan materi serta cara penyampaian sehingga menarik dan menyenangkan. Sistem pengajaran yang baik adalah yang dapat menyeimbangkan antara materi ajar praktek dan materi ajar teori. Pemilihan materi ajar yang sesuai dengan perkembangan anak juga menjadi salah satu penentu keberhasilan sistem pengajaran yang dirancang oleh seorang pendidik. Pada penelitian kali ini peneliti memilih materi ajar bolabasket dikarenakan permainan bolabasket kurang diminati peserta didik di sekolahsekolah karena mayoritas dari mereka lebih berminat pada bolavoli dan sepakbola.

Permainan bolabasket itu sendiri adalah permainan yang dimainkan oleh dua regu yang setiap regunya terdiri dari lima orang dan didalam lapangan terdapat dua ring yang berguna untuk memasukan bola. Ada beberapa teknik dasar dalam permainan bolabasket sebagai berikut: ball handling, dribbling. passing, catching, shooting, rebounding (offense \& defense), pivoting, setting screen, offensive moves (with \& without the ball), defensive moves (slide step) (PERBASI, 2006:12). Sedangkan menurut (Wissel, 2000: 2) diantaranya adalah foot work (gerakan kaki), shooting (menembak), passing (operan) dan menangkap, dribel, bergerak dengan bola, bergerak tanpa bola, dan bertahan. Tujuan permainan bolabasket yaitu memasukan bola kedalam ring lawan sebanyak-banyaknya, shooting menjadi salah satu teknik dasar dalam bolabasket yang penting untuk dikuasai secara baik. Menurut Kosasih (2008: 23) ada berbagai macam 


\begin{tabular}{|c|c|}
\hline & Journal STAND: Sports and Development \\
unttp://jurnal.unipasby.ac.id/index.php/stand/about/submissions \\
jurnal.stand@unipasby.ac.id
\end{tabular}

shooting pada bolabasket yaitu, lay up shoot, set shoot, jump shoot, dan free throw shoot. Free throw shoot adalah teknik menembak bola dengan satu tangan dan dilakukan tanpa lompatan. Tembakan ini dilakukan saat pemain melakukan lemparan bebas atau ketika pemain tidak mendapatkan halangan saat shooting selama pertandingan berlangsung.

Menurut pengalaman peneliti saat melakukan pengajar, banyak peserta didik yang belum bisa melakukan gerakan shooting free throw, peserta didik hanya asal melempar bola dengan harapan bola masuk ke ring. Untuk itu peneliti mencoba menerapkan metode pembelajaran quantum teaching yang belum pernah diterapkan di sekolah dalam materi ajar free throw dalam bola basket dengan harapan dapat meningkatkan hasil belajar sisiwa.

Quantum teaching adalah pengubahan belajar meriah, dengan segala nuansanya. Quantum Teaching juga menyertakan segala kaitan, interaksi, dan perbedaan yang memaksimalkan momen belajar. Quantum teaching berfokus pada hubungan dinamis dalam lingkungan kelas interaksi yang mendirikan kerangka untuk belajar (DePorte, 2010: 32). Adapun tujuan dari pembelajaran quantum menurut Deporter (2010:35) adalah untuk menciptakan lingkungan belajar yang efektif, menciptakan proses belajar yang menyenangkan, menyesuaikan kemampuan otak dengan apa yang dibutuhkan oleh otak, untuk membantu meningkatkan keberhasilan hidup dan karir dan untuk membantu mempercepat dalam pembelajaran. Pembelajaran quantum berpangkal pada psikologi kognitif, dan bukan fisika quantum meskipun serba sedikit istilah dan konsep quantum dipakai, pembelajaran quantum juga bersifat humanistis dan lebih konstruktivistis. Kegiatan pembelajaran quantum teaching dikenal dengan sistem T-A-N-D-U-R: (1) tumbuhkan minat, (2) alami, (3) namai atau penyajian materi, (4) demonstrasi tentang pemerolehan pengetahuan oleh peserta didik, (5) ulangii yang dilakukan oleh peserta didik, (6) rayakan atas usaha peserta didik. Dari uraian diatas peneliti ingin melakukan penelitian untuk mengetahui Apakah ada pengaruh model pembelajaran quantum teaching terhadap hasil belajar shooting free throw dalam permainan bolabasket

\section{METODE PENELITIAN}

Penelitian ini merupakan penelitian kuantitatif. Sedangkan jenis penelitian ini adalah penelitian eksperimen. Penelitian eksperimen adalah penelitian yang dilakukan secara ketat untuk mengetahui sebab akibat di antara variabel. Salah satu ciri utama dari penelitian eksperimen adalah adanya perlakuan (Maksum, 2012: 65). Sedangkan desain penilitian yang dipilih adalah one group pretest-posttest design. Variabel dalam penelitian ini yaitu variable bebas adalah model pembelajara quantum teaching sedangkan variabel terikat adalah penelitian ini 
adalah hasil belajar shooting free throw permainan bolabasket. Populasi dari penelitian ini adalah seluruh peserta didik kelas XI SMK Dwija Bhakti Jombang. Karena jumlah populasi yang terlalu besar maka peneliti memakai cluster random sampling sebagai cara pengambilan sampel. Sehingga sampel yang didapat adalah kelas XI TKJ SMK Dwija Bhakti Jombang yang berjumlah 19 peserta didik. Teknik penggumpulan data dalam penelitian ini adalah tes shooting free throw pada permainan bolabasket Sodikun (1992: 125)

Analisa data dalam penelitian ini menggunakan beberapa perhitungan statistik:

1. Uji prasyarat analisis

a) Deskriptif

Dalam penelitian ini cara untuk mencari nilai maximum, minimum, mean dan standart devisiasi.

b) Uji Normalitas

Uji normalitas menggunakan teknik analisis Kolmogorov-Smirnov.

\section{Uji Statistik Hipotesis}

Dalam penelitian ini cara pengujian hipotesis menggunakan teknik analisis paired sample test.

\section{HASIL DAN PEMBAHASAN}

a. Deskriptif

Deskriptif data berdasarkan pada hasil tes free throw yang akan disajikan pada tabel di bawah ini yang meliputi mean (rata-rata), nilai maksimal, nilai minimal dan standart deviation.

\begin{tabular}{lrrrrc}
\hline \multicolumn{5}{c}{ Tabel Descriptive Statistics } \\
& N & $\begin{array}{c}\text { Mini } \\
\text { mum }\end{array}$ & $\begin{array}{c}\text { Maxim } \\
\text { um }\end{array}$ & Mean & $\begin{array}{c}\text { Std. } \\
\text { Deviati } \\
\text { on }\end{array}$ \\
\hline Pretes & 19 & 41 & 69 & 51.42 & 7.044 \\
Posttest & 19 & 58 & 82 & 68.79 & 8.355 \\
Valid N & 19 & & & & \\
(listwise) & 19 & & & & \\
\hline
\end{tabular}

Berdasarkan table di atas dapat diketahui bahwa:

1. Hasil dari belajar menembak free throw sebelum diberi perlakuan model pembelajaran quantum teaching atau ratarata pre-test yaitu sebesar 51,42 sedangkan hasil belajar minimum sebelum diberi perlakuan adalah 41,00 dan nilai maksimal adalah 69,00.

2. Hasil dari belajar menembak free throw setelah diberi perlakuan model pembelajaran quantum teaching atau ratarata post-test yaitu sebesar 68,79 sedangkan hasil belajar minimum setelah diberi perlakuan adalah 58,00 dan nilai maksimal adalah 82,00

3. Standart deviation diperoleh dari hasil sebelum diberi perlakuan dan sesudah diberi perlakuan model pembelajaran quantum teaching atau hasil antara pretest dan post-test dapat dilihat relatif besar, yaitu 7.044 dengan 8.35

b. Uji Normalitas

Uji normalitas dilakukan untuk mengatahui apakah data penelitian berdistribusi normal atau tidak. Pengujian 


\begin{tabular}{|c|c|}
\hline & Journal STAND: Sports and Development \\
unttp://jurnal.unipasby.ac.id/index.php/stand/about/submissions \\
jurnal.stand@unipasby.ac.id
\end{tabular}

normalitas menggunakan teknik analisis Kolmogorov-Smirnov. Hasil uji normalitas data pre-test dan post-test disajikan

\begin{tabular}{lcccccc}
\hline \multicolumn{8}{c}{ Tests of Normality } \\
& \multicolumn{2}{c}{$\begin{array}{c}\text { Kolmogorov- } \\
\text { Smirnova }\end{array}$} \\
& $\begin{array}{c}\text { Statisti } \\
\text { c }\end{array}$ & Df & Sig. & $\begin{array}{c}\text { Statisti } \\
\text { c }\end{array}$ & Df & Sig. \\
& .209 & 19 & .028 & .885 & 19 & .027 \\
\hline $\begin{array}{l}\text { Pretes } \\
\text { Postte } \\
\text { st }\end{array}$ & .149 & 19 & $.200^{*}$ & .949 & 19 & .386 \\
\hline
\end{tabular}

sebagai berikut ini:

Hasil uji normalitas data pre-test dan post-test mempunyai nilai signifikansi lebih besar dari 0,05 yaitu 0.28 dan 0.200, sehingga dapat disimpulkan bahwa semua data penelitian ini berdistribusi normal.

\section{c. Uji Hipotesis}

Pengujian hipotesis dalam penelitin ini bertujuan untuk membuktikan adanya perbedaan pengaruh penggunaan model pembelajaran quantum teaching terhadap hasil belajar free throw bolabasket. Analisis yang dilakukan untuk menguji hipotesis dalam penelitian ini adalah uji-t dan menggukan program SPSS versi 20. Adapun hasilnya sebagai berikut:

\begin{tabular}{lccccc}
\hline & \multicolumn{1}{c}{$\begin{array}{c}\text { Std. } \\
\text { Mean }\end{array}$} & $\begin{array}{c}\text { Deviation } \\
\text { Postte }\end{array}$ & t hit & N & Sig \\
\hline $\begin{array}{l}\text { st }- \\
\text { Pretes } \\
\mathrm{t}\end{array}$ & 1.757051 & 7.33500 & 10.441 & 18 & .000 \\
\hline
\end{tabular}

Berdasarkan table di atas maka diketahui nilai $t_{\text {hitung }}>\mathrm{t}_{\text {tabel }}(10.44>1.73)$ maka Ho ditolak artinya ada pengaruh yang signifikan antara (sebelum-sesudah) pemberian perlakuan model pembelajaran quantum teaching terhadap hasil belajar shooting free throw bolabasket.

\section{Pembahasan}

Melalui model pembelajaran quantum teaching menunjukan bahwa hasil belajar shooting free throw dapat meningkat. Hal ini dapat dibuktikan pada penelitian yang relevan. Peningkatan hasil belajar shooting free throw peserta didik yang diberikan model pembelajaran quantum teaching terjadi karena model quantum teaching memiliki langkahlangkah yang disebut dengan TANDUR yang sangat cocok diterapkan dalam pendidikan jasmani, olahraga dan kesehatan.

Berdasarkan pada rumusan masalah, peneliti memilih model pembelajaran quantum teaching karena model pembelajaran tersebut dapat mempermudah proses belajar peserta didik. Sehingga pada saat melakukan tes shooting free throw hasil belajar peserta didik dapat meningkat.

Menurut (Deporter, 2010:53) Model pembelajaran quantum teaching adalah model yang digunakan dalam rancangan penyajian dalam belajar yang dirangkai menjadi sebuah paket yang multisensori, multikecerdasan, dan kompatibel dengan otak, mencakup petunjuk spesifik untuk menciptakan lingkungan belajar 


\begin{tabular}{|c|c|}
\hline & $\begin{array}{c}\text { Journal STAND: Sports and Development } \\
\text { http://jurnal.unipasby.ac.id/index.php/stand/about/submissions } \\
\text { umipa Sumalmya }\end{array}$ \\
\hline
\end{tabular}

yang efektif, merancang kurikulum, menyampaikan isi, dan memudahkan proses belajar

Dengan demikian, model pembelajaran quantum teaching dapat digunakan untuk meningkatkan hasil belajar peserta didik terutama dalam pembelajaran pendidikan jasmani, olahraga dan kesehatan

\section{KESIMPULAN}

Berdasarkan hasil penelitian yang telah dikemukakan, dapat diambil kesimpulan bahwa, penerapan model pembelajaran quantum teaching berpengaruh terhadap hasil belajar shooting free throw bolabasket.

\section{REFERENSI}

Anwar, M. H. 2005. Pendidikan Jasmani Sekolah Dasar Sebagai Wahana Kompensasi Gerak Anak. Jurnal Pendidikan Jasmani Indonesia Vol 3.

Deporte, B., dkk. 2010. Quantum Teaching : Mempraktikan Quantum Learning di Ruang-Ruang Kelas. Bandung: Kaifa

Kosasi, D. 2008. fundamental basketball (first step to win). Karangturi media. Semarang..

Maksum, A. 2012. Metodologi Penelitian dalam Olahraga.Unesa University Press. Surabaya.

PB PERBASI. 2006 Panduan Pelatihan Pelatih/Wasit dan Juri Cabang Olaraga Bolabasket. Surabaya.

Sudianto, M. 2005. Bola Basket. Jakarta: PT. Rajagrafindo Persada

Wissel, H. 1996 Bola Basket. PT Rajagrafindo Persada. Jakarta 